\title{
Sugar beet yield and quality as affected by concentration of boron and methanol application.
}

\author{
Nemeata Alla, H.E.A.; E.A.E. Nemeata Alla and S.S.Zalat \\ Sugar Crop Res. Ins., Agric. Res. Center, Giza \\ Corresponding author: Nemeatalla@yahoo.com
}

\begin{abstract}
The aim of this research is to assess the effect of foliar spraying with boron and methanol levels and time of methanol application. Two field experiments were conducted at EL-Haamoul district Kafer EL-Sheikh Governorate, Egypt during 2012/2013 and 2013/2014 seasons. Strip-plot design was used in both seasons. Main plot (vertical) allocated with Boron levels $(0,1$ and $1.5 \mathrm{Kg} / \mathrm{fed}$.) sub plot (horizontal plots) takes Methanol rates $(15 \%, 30 \%$ and $45 \% \mathrm{v} / \mathrm{v})$ this solution were sprayed overhead 3 times in two weeks intervals starting after 55 and repeated at 70 and 80 days from sowing with (zero, one, two and three times) were distributed in sub-sub plots. Obtained results indicated that addition boron on foliage as foliar spraying at rate of $1.5 \mathrm{Kg} / \mathrm{fed}$. Significantly increased affected on the values of most characters under study i.e. root dimension, yields of root, top and sugar per fed. In additions to impurities $(\mathrm{Na}, \mathrm{K}$ and $\alpha-\mathrm{N})$ and quality traits as sucrose and sugar losses percentages. On the other hand purity and extractability percentage gave the highest values with control treatments. This was true in both seasons. Application of methanol solution at level $45 \%$ take the mentioned trend of boron and gave the highest values $45 \%$ compared with level $15 \%$ which recorded the lowest values with purity and extractability percentages. Times of foliar applications of methanol on sugar beet leaves at three times recorded the highest values for most traits as boron and methanol levels except impurities content ( $\mathrm{Na}, \mathrm{K}$, $\alpha-\mathrm{N})$. alkalinity, purity, extractability\% which recorded in significant effect on values of these traits in both seasons. Whereas, sugar losses $\%$ showed significant increase in the second season only, sugar extractable $\%$ and sugar yield (ton/fed.). Significant interaction effects were found between factors under study on some traits in both seasons.
\end{abstract}

Keywords: Sugar beet, yield, quality, boron, methanol

\section{Introduction}

Sugar beet production is an essential component of agricultural economics in money countries. Sugar beet contributes to about $40 \%$ of world production. Sugar beet is not only important for sugar production, but it is beneficial crop in agronomic rotation and reclaimed soil salinity as in Egypt. Boron fertilizer is by for the most important trace elements needed for sugar beet because without an adequate supply the yield and quality of roots will be depressed (Cooke and Scotte 1993). Soil application as well as, foliar spray of boron were equally effective, hence the root fresh weight, sucrose $\%$, root and top yield significantly increased by increasing boron levels (Jaszczolt, 1998) and Gezgum et al. (2001) showed that consumption of $0.3 \mathrm{Kg} \mathrm{B} / \mathrm{ha}$. increased root yield, sucrose yield compared to control and consumption of boron in large amount caused reduction in yield and sugar production in all methods of application either soil or sparing applications. Recently methanol spry is a method, which increase crop Co2 fixation in unites area. The main reason for using of methanol due to generate by plant throughout the demethylation of pectin - py pectin methyl esterase for tightening of the cell especially throughout the early stage of leaf expansion Lee, et al. (2006). Methanol accumulates in the intercellular air space or in the liquid pool at night when the stomata close and is rapidly converted to formaldehyde formic acid and $\mathrm{co} 2$ to prevent the damage by alcohol oxidase Gout et al. (2000). In addition, methanol is very important to sugar beet when face drought stress conditions.

\section{Materials and methods}

Two field experiments were conducted in clay soil at EL-Haamoul Center Kafer EL-Sheikh Governorate, Egypt during 2012/2013 and 2013/2014 seasons. The preceding crop was rice in the two seasons. Detailed soil properties for two growing seasons are listed in Table (1):

The experimental soil was fertilized with $90 \mathrm{Kg}$ $\mathrm{N} /$ fad. in form of Urea $46 \% \mathrm{~N}$. at two equal doses at 4 and 8 true leaves. Also $24 \mathrm{Kg} \mathrm{K}_{2} \mathrm{O} /$ fad. in form of potassium sulphate $\left(48 \% \mathrm{~K}_{2} \mathrm{O}\right)$ and $30 \mathrm{Kg} \mathrm{p}_{2} \mathrm{O}_{5} / \mathrm{fad}$. in the form of calcium super phosphate $\left(15.5 \% \mathrm{p}_{2} \mathrm{O}_{5}\right)$ during soil preparation. Strip-plot design with three replications was used. The horizontal plots were assigned to boron levels $(0,1$ and $1.5 \mathrm{Kg} \mathrm{B} / \mathrm{fad}$.) in form Boric acid $\mathrm{H}_{3} \mathrm{Bo}_{3}$. Vertical plot contained Methanol levels $(0,15 \%, 30 \%$ and $45 \% /$ fad.) in form of Methanol and three times of applications (one, two and three times). Application time of the Methanol at (55, 70 and 85 days after sowing) were devoted in sub-sub-plot included which have six ridges $55 \mathrm{~cm}$ apart and $9 \mathrm{~m}$ long. 
Table1. Physical and chemical properties soil at the experimental sites in 2012/2013 and 2013/2014 seasons.

\begin{tabular}{lcc}
\hline \multirow{2}{*}{ Soil characters } & \multicolumn{2}{c}{ seasons } \\
\cline { 2 - 3 } & $2012 / 2013$ & $2013 / 2014$ \\
\hline PH 1:2.5 & 8.4 & 8.15 \\
EC m mhos/cm & 3.35 & 3.41 \\
Organic matter\% & 1.73 & 1.80 \\
Clay & 52.60 & 53.47 \\
Silt & 23.87 & 23.16 \\
Sand & 23.53 & 23.37 \\
Texture class & Clay & Clay \\
Available: & & \\
N (ppm) & 14.98 & 15.45 \\
P (ppm) & 6.23 & 6.70 \\
K (ppm) & 278.77 & 288.54 \\
Anions meq/L & & 5.88 \\
$\mathrm{Hco}_{3}^{-}$ & 5.69 & 6.92 \\
$\mathrm{Cl}^{-}$ & 6.71 & 0.34 \\
$\mathrm{So}_{4}^{-}$ & 0.28 & 0.0 \\
$\mathrm{Co}_{3}^{-}$ & 0.0 & \\
\hline
\end{tabular}

Both Boric acid and Methanol were added as foliar spraying. Sowing takes place on 20 October 2013 and 2 November 2014 seasons respectively.

Seed of multigerm cultivar "Farida" were sown in hills $20 \mathrm{~cm}$ apart at rate of 3-4 seeds/ hill. At forty days after sowing, thinning to one plant/hill was done. Other cultural practices were done as recommended. At maturity after (210 days from sowing), the area of $19.8 \mathrm{~m}^{2}$ of each plot were harvested to obtain root and top yields. Ten guarded plants were taken at random to estimate root dimensions (length and diameter) and the quality parameters were determined as follows.

1. Sucrose percentage was determined using the method described by Le Doct (1927) and juice purity using to the method of Silin and Silina (1977).

2. Potassium and sodium (Flame photometry).

3. Alpha $(\alpha)$ amino- Nitrogen determined using ninhydydrin. Hydrinda ntian method according to Carruthers et al. (1960).

4. Purity, sugar losses to molasses, extractable sugar, extractability\% were calculated according to the following formulas:

- Purity $\%=99.36-\{14.27(\mathrm{v} 1+\mathrm{v} 2+\mathrm{v} 3)\} / \mathrm{v} 4$ Devillers, (1988).

5. Sugar losses to molasses $(\mathrm{SM})=(\mathrm{v} 1+\mathrm{v} 2) 0.14+$ v4 $\times 0.25+0.5$ Devillers, (1988).

6. Extractable sugar $=\mathrm{v} 4-(\mathrm{SM})-0.6$ Dexter et al. (1967).

7. Extractability $\%=$ extractable sugar $\% / v 4$.

Where:

$\begin{array}{ll}\mathrm{V} 1=\text { sodium } & \mathrm{V} 2=\text { potassium } \\ \mathrm{V} 3=\alpha \text { amino } \mathrm{N} & \mathrm{V} 4=\text { sugar percentage }\end{array}$

8. Sugar yield per faddan was calculated form root yield per faddan multiplied by sucrose percentage and purity $\%$.
- $\quad$ Sugar yield $=$ root yield $\times$ sugar percentage $\times$ purity $\%$.

The analysis of variance was carried out according to Gomez and Gomez (1984). Treatment means were compared by Duncan's Maltiple range test Duncan, 1955). All statistical analysis was performed using analysis of variance technique by means of "CoHort" computer software package.

\section{Result and discussion}

1-Root length, root diameter and root/top ratio.

Data presented in Table (2) clearly showed that addition boron fertilizer as foliar spraying to sugar beet significantly increased root dimension and root /top ratio by increasing boron levels from zero to 1.5 $\mathrm{Kg} \mathrm{B} / \mathrm{fad}$. the positive effect of boron may be due to its effective role in cell elongation of root cell. These result are agreement with these obtained by Abido (2012) and Armin and Asgharipour (2012). and Ali (2015).

Concerning to effect of foliar application of methanol at different levels, data in Table 2 showed that spraying methanol at levels on sugar beet exhibited significant differences between values of root dimension and the ratio between root and top (root/top) in both seasons. Foliar spraying at levels $45 \%$ gave maximum values of mentioned traits. The advantage in these traits due to effect of methanol on increase of photo synthesis in leaves with delaying leaf senescence's and by effecting rate of ethylene production, finally due to increases in root and foliage yields. Similar results were found by Nadali et al. (2010). 
Table 2. Root length and diameter and root/top ratio as affected by boron and methanol levels and time of methanol foliar applications in 2012/2013 and 2013/2014 season.

\begin{tabular}{|c|c|c|c|c|c|c|}
\hline \multirow{3}{*}{ Factor } & \multicolumn{2}{|c|}{ Root length } & \multicolumn{2}{|c|}{ Root diameter } & \multicolumn{2}{|c|}{ Root/top ratio } \\
\hline & \multicolumn{6}{|c|}{ seasons } \\
\hline & $2012 / 2013$ & $2013 / 2014$ & $2012 / 2013$ & $2013 / 2014$ & $2012 / 2013$ & $2013 / 2014$ \\
\hline \multicolumn{7}{|c|}{ Boron fertilizer rate $(\mathrm{Kg} /$ fad. $)(\mathrm{B})$} \\
\hline 0 & $29.78 c$ & $29.36 \mathrm{c}$ & $10.46 b$ & $10.36 \mathrm{c}$ & $2.54 \mathrm{c}$ & $2.78 \mathrm{c}$ \\
\hline 1 & $31.35 \mathrm{~b}$ & $32.74 b$ & $10.91 \mathrm{ab}$ & $11.03 b$ & $3.01 \mathrm{~b}$ & $3.58 b$ \\
\hline 1.5 & $32.44 \mathrm{a}$ & $34.55 \mathrm{a}$ & $11.66 \mathrm{a}$ & $12.00 \mathrm{a}$ & $3.50 \mathrm{a}$ & $3.82 \mathrm{a}$ \\
\hline F -test & $* *$ & $* *$ & $*$ & $* *$ & $* *$ & $* *$ \\
\hline \multicolumn{7}{|c|}{ Concentration of methanol \%. (M) } \\
\hline $15 \%$ & $30.80 \mathrm{c}$ & $31.31 \mathrm{c}$ & 10.81 & 10.93 & $2.92 \mathrm{c}$ & $3.18 \mathrm{c}$ \\
\hline $30 \%$ & $31.24 \mathrm{~b}$ & $32.33 b$ & 10.98 & 11.08 & $3.02 b$ & $3.41 \mathrm{~b}$ \\
\hline $45 \%$ & $31.53 \mathrm{a}$ & $32.84 \mathrm{a}$ & 11.25 & 11.38 & $3.12 \mathrm{a}$ & $3.60 \mathrm{a}$ \\
\hline $\mathrm{F}$-test & $* *$ & $* *$ & NS & NS & $* *$ & $* *$ \\
\hline \multicolumn{7}{|c|}{ No. of foliar methanol application $(\mathrm{N})$} \\
\hline 0 & $30.36 b$ & $31.36 \mathrm{c}$ & $10.65 b$ & $10.81 b$ & $2.86 \mathrm{c}$ & $3.37 \mathrm{~b}$ \\
\hline 1 & $31.33 \mathrm{a}$ & $32.24 b$ & $11.04 \mathrm{ab}$ & $11.15 \mathrm{ab}$ & $3.02 b$ & $3.37 \mathrm{~b}$ \\
\hline 2 & $31.46 \mathrm{a}$ & $32.33 b$ & $11.11 \mathrm{a}$ & $11.21 \mathrm{ab}$ & $3.07 \mathrm{ab}$ & $3.39 \mathrm{ab}$ \\
\hline 3 & $31.60 \mathrm{a}$ & $32.60 \mathrm{a}$ & $11.24 \mathrm{a}$ & $11.33 \mathrm{a}$ & $3.12 \mathrm{a}$ & $3.46 \mathrm{a}$ \\
\hline $\mathrm{F}$-test & $* *$ & $* *$ & $*$ & $*$ & $* *$ & $*$ \\
\hline \multicolumn{7}{|c|}{ Inter action } \\
\hline $\mathrm{B} \times \mathrm{M}$ & $* *$ & NS & NS & NS & NS & NS \\
\hline $\mathrm{B} \times \mathrm{N}$ & NS & NS & NS & NS & NS & NS \\
\hline $\mathrm{M} \times \mathrm{N}$ & NS & NS & NS & NS & NS & NS \\
\hline $\mathrm{B} \times \mathrm{V} \times \mathrm{N}$ & NS & NS & NS & NS & NS & NS \\
\hline
\end{tabular}

Regarding to the effect of number of foliar spraying of methanol on root dimension and root/top ratio, data as shown in Table (2) revealed that with repeated times of foliar spraying of methanol in 3 times lead to significant increase in values of mentioned traits except between 3 and 2 times in root length and root diameter in the first season only compared to the other two times, this was true in both seasons.

Significant interaction effects were found between boron levels $\times$ methanol levels on root length in first seasons. Maximum values were obtained in this interaction resulted from addition high levels of boron or methanol and 3 times of applications more than any one alone.

\section{2- Top, Root and Sugar yields (ton/fad.)}

Results in Table (3) showed the effect of born rates on top, root and sugar yields in both seasons. Averages of three mentioned traits were significantly increased in both seasons with increasing the dose of boron up to $1.5 \mathrm{Kg} / \mathrm{fad}$. applied as foliar spraying which gave the highest values. This advantage of boron application may be due to important function of boron in increase plant metabolism, development and growth. Gobara and Mekki (2005) concluded similar results. With respect to effect of foliar spraying of methanol solution at different concentrations 15,30 and $45 \%$ on sugar beet results in Table (3) pointed out significant increase in top, root and sugar yields when sugar beet by increasing methanol level up to $45 \%$ which recorded maximum yields in both seasons. The increases in these traits may be due to the advantage role of methanol in reducing photo respiration during growth stage which reflected on significant increase in top, root and sugar yields. These observations were in agreement with these obtained by Nadali et al. (2010), Iman Nadali et al. (2014).

Regarding to the effect of number of methanol applications, addition 3 times gave the highest values of top and root sugar yields in both seasons. Significant differences were observed between mean values of top, root in both seasons whereas; sugar yield significantly was affected by foliar spraying in the second season only. Foliar application three times gave a positive effect by adequate supplying time to gave good effect on these traits by shifted photo respiration from catabolism to anabolism which enhance net photosynthesis which increased the yields.

No significant interaction effect was found among the studied factor on root and sugar yield in both seasons. Whereas, significant effect was found between boron levels $\times$ times of spraying methanol and top yield in the first season only (Table 3-a) which indicated the highest top yield was 16.18 ton/fad. obtained from sugar beet sprayed three times by $1.5 \mathrm{Kg} / \mathrm{fad}$. boron and three applications of methanol treatment. 
Table 3. Top, root and sugar\% as affected by boron and methanol levels and number of methanol foliar applications in 2012/2013 and 2013/2014 season.

\begin{tabular}{|c|c|c|c|c|c|c|}
\hline \multirow{3}{*}{ Factor } & \multicolumn{2}{|c|}{ Top yield } & \multicolumn{2}{|c|}{ Root yield } & \multicolumn{2}{|c|}{ Sugar yield } \\
\hline & \multicolumn{6}{|c|}{ seasons } \\
\hline & $2012 / 2013$ & $2013 / 2014$ & $2012 / 2013$ & $2013 / 2014$ & $2012 / 2013$ & $2013 / 2014$ \\
\hline \multicolumn{7}{|c|}{ Boron fertilizer rate (Kg/fad.) (B) } \\
\hline 0 & $12.90 \mathrm{c}$ & $10.69 \mathrm{c}$ & $24.76 \mathrm{c}$ & $27.86 \mathrm{bc}$ & $3.79 \mathrm{c}$ & $4.02 \mathrm{c}$ \\
\hline 1 & $14.82 b$ & $11.45 b$ & $27.07 b$ & $29.75 b$ & $4.18 b$ & $4.35 b$ \\
\hline 1.5 & $15.94 \mathrm{a}$ & $12.56 \mathrm{a}$ & $30.71 \mathrm{a}$ & $30.18 \mathrm{a}$ & $4.91 \mathrm{a}$ & $4.81 \mathrm{a}$ \\
\hline $\mathrm{F}$-test & ** & ** & $* *$ & $* *$ & $* *$ & $* *$ \\
\hline \multicolumn{7}{|c|}{ Concentration of methanol \%. (M) } \\
\hline $15 \%$ & $14.15 b$ & $11.34 \mathrm{c}$ & $26.84 \mathrm{c}$ & $26.76 \mathrm{c}$ & $4.14 \mathrm{~b}$ & $4.29 b$ \\
\hline $30 \%$ & $14.56 \mathrm{ab}$ & $11.56 \mathrm{~b}$ & $27.57 b$ & $29.04 b$ & $4.26 \mathrm{ab}$ & $4.37 \mathrm{~b}$ \\
\hline $45 \%$ & $14.96 \mathrm{a}$ & $11.62 \mathrm{a}$ & $28.12 \mathrm{a}$ & $31.99 a$ & $4.74 \mathrm{a}$ & $4.52 \mathrm{a}$ \\
\hline $\mathrm{F}$-test & $* *$ & $* *$ & $* *$ & $* *$ & $*$ & $* *$ \\
\hline \multicolumn{7}{|c|}{ No. of foliar methanol (N) } \\
\hline 0 & $13.89 \mathrm{c}$ & $10.98 \mathrm{c}$ & $26.14 \mathrm{c}$ & $28.58 \mathrm{c}$ & 3.96 & $4.15 c$ \\
\hline 1 & $14.57 \mathrm{~b}$ & $11.56 \mathrm{~b}$ & $27.66 b$ & $29.04 b c$ & 4.32 & $4.40 \mathrm{~b}$ \\
\hline 2 & $14.81 \mathrm{ab}$ & $11.78 \mathrm{a}$ & $27.94 \mathrm{ab}$ & $29.29 b$ & 4.44 & $4.47 \mathrm{ab}$ \\
\hline 3 & $14.95 \mathrm{a}$ & $11.94 \mathrm{a}$ & $28.30 \mathrm{a}$ & $30.15 \mathrm{a}$ & 4.44 & $4.55 \mathrm{a}$ \\
\hline $\mathrm{F}$-test & $* *$ & $* *$ & $* *$ & $* *$ & NS & $* *$ \\
\hline \multicolumn{7}{|c|}{ Inter action } \\
\hline $\mathrm{B} \times \mathrm{M}$ & NS & NS & NS & NS & NS & NS \\
\hline $\mathrm{B} \times \mathrm{N}$ & $* *$ & NS & NS & NS & NS & NS \\
\hline $\mathrm{M} \times \mathrm{N}$ & NS & NS & NS & NS & NS & NS \\
\hline $\mathrm{B} \times \mathrm{V} \times \mathrm{N}$ & NS & NS & NS & $\mathrm{NS}$ & NS & NS \\
\hline
\end{tabular}

Table 3-a.Top yield (ton /fad.) as affected by the interaction between boron fertilizer rate and times of action methanol in 2012/2013 seasons.

\begin{tabular}{ccccc}
\hline \multirow{2}{*}{ Boron fertilizer rate Kg/fad. } & \multicolumn{4}{c}{ No. of application of methanol } \\
\cline { 2 - 5 } & 0 & 1 & 2 & 3 \\
\cline { 2 - 5 } 1 & $11.54 \mathrm{f}$ & $12.94 \mathrm{e}$ & $13.44 \mathrm{de}$ & $13.68 \mathrm{~d}$ \\
\hline 1.5 & $14.53 \mathrm{c}$ & $14.82 \mathrm{c}$ & $14.95 \mathrm{c}$ & $14.99 \mathrm{bc}$ \\
\hline
\end{tabular}

\section{3- Impurities traits (Na, $\mathrm{K}$ and $\alpha-\mathrm{N})$.}

Impurities contents are very important to juice quality of sugar beet. Data tabulated in Table (4) show the effect of boron rates on impurities $(\mathrm{Na}, \mathrm{K}$ and $\alpha-\mathrm{N})$. Increasing boron rates from zero to 1.5 $\mathrm{Kg} / \mathrm{fad}$. led to significant increase in all values of impurities. These results disagreed the Gobara and Mekki (2005) who observed that all these contents decreased with increasing boron levels from zero to $1.5 \mathrm{Kg} \mathrm{B} / \mathrm{fad}$.

Methanol rates effects on impurities are presented in Table (4). All impurities in terms ( $\mathrm{Na}, \mathrm{K}$ and $\alpha-\mathrm{N})$ were significantly increased with increasing methanol rates from $15 \%$ to $45 \%$ this was true in both seasons. Similar results were obtained by Nadali et al. (2010).

Regarding to the effect of number of methanol foliar applications on sugar beet impurities $\mathrm{Na}, \mathrm{K}$ and $\alpha-\mathrm{N}$ Table (4) showed that no significant effect on all impurities traits.

No significant interaction effects were found among three factors under study on impurities content in terms $\mathrm{Na}, \mathrm{K}$ and $\alpha-\mathrm{N}$ in both seasons.
Alkaline coefficient (A.C), purity\% and sugar \%.

Alkaline coefficient is very important indicator for sugar beet quality. The value of (A.C) must be not decrease than 1.8 , if it decrease than 1.8 this mean that sugar beet juice quality not good. Data presented in Table (5) showed that no significant effect on these traits in both seasons due to levels of boron or levels and times of methanol applications.

No significant interaction effect were recorded in two growing seasons resulted from interaction between any factor with other three factor under study. Effect of either boron or methanol levels and times of methanol applications on purity\% are tabulated in Table (5).

Application boron as foliar spraying on sugar beet at dose $1.5 \mathrm{Kg} / \mathrm{fad}$. caused to significant decrease in purity $\%$ in both seasons compared to other two levels ( zero and $1.0 \mathrm{Kg} / \mathrm{fad}$.). These resulted may be due to increasing impurities values and increasing root content from total soluble solid rates than sucrose\%. Gobara and Mekki (2005) and Ali Mekdad (2015) disagreed our results because they reported that purity\% was increased with increasing boron levels from zero to $2.0 \mathrm{Kg} / \mathrm{fad}$. 
Table 4. Na, K and $\alpha-\mathrm{N}$ (Meg / 100g sugar beet) as affected by boron levels, methanol levels and time of methanol foliar applications in 2012/2013 and 2013/2014 seasons.

\begin{tabular}{|c|c|c|c|c|c|c|}
\hline \multirow{3}{*}{ Factor } & \multicolumn{2}{|c|}{$\mathrm{Na}$} & \multicolumn{2}{|c|}{$\mathrm{K}$} & \multicolumn{2}{|c|}{$\alpha-\mathrm{N}$} \\
\hline & \multicolumn{6}{|c|}{ seasons } \\
\hline & $2012 / 2013$ & $2013 / 2014$ & $2012 / 2013$ & $2013 / 2014$ & $2012 / 2013$ & $2013 / 2014$ \\
\hline \multicolumn{7}{|c|}{ Boron fertilizer rate ( $\mathrm{Kg} / \mathrm{fad}$.) (B) } \\
\hline 0 & $2.45 \mathrm{c}$ & $2.57 \mathrm{c}$ & $5.63 c$ & $5.43 c$ & $3.44 \mathrm{c}$ & $3.78 \mathrm{c}$ \\
\hline 1 & $2.73 b$ & $3.00 \mathrm{~b}$ & $6.28 \mathrm{~b}$ & $6.61 b$ & $3.92 \mathrm{~b}$ & $4.02 \mathrm{~b}$ \\
\hline 1.5 & $3.13 \mathrm{a}$ & $3.49 \mathrm{a}$ & $7.36 \mathrm{a}$ & $7.20 \mathrm{a}$ & $4.31 \mathrm{a}$ & $4.74 a$ \\
\hline F -test & ** & $* *$ & $* *$ & ** & ** & ** \\
\hline \multicolumn{7}{|c|}{ Concentration of methanol \%. (M) } \\
\hline $15 \%$ & $2.67 \mathrm{~b}$ & $2.87 \mathrm{~b}$ & $6.21 \mathrm{c}$ & $6.18 \mathrm{c}$ & $3.73 b$ & $4.04 \mathrm{~b}$ \\
\hline $30 \%$ & $2.76 \mathrm{ab}$ & $3.03 \mathrm{ab}$ & $6.42 b$ & $6.36 \mathrm{~b}$ & $3.92 \mathrm{a}$ & $4.18 \mathrm{ab}$ \\
\hline $45 \%$ & 2.88 & 3.16 & $6.63 \mathrm{a}$ & $6.70 \mathrm{a}$ & $4.03 \mathrm{a}$ & $4.32 \mathrm{a}$ \\
\hline F -test & * & * & $*$ & ** & $* *$ & * \\
\hline \multicolumn{7}{|c|}{ No. of foliar methanol (N) } \\
\hline 0 & 2.70 & 2.97 & 6.35 & 6.29 & 3.82 & 4.13 \\
\hline 1 & 2.78 & 3.00 & 6.38 & 6.34 & 3.88 & 4.16 \\
\hline 2 & 2.79 & 3.03 & 6.45 & 6.42 & 3.91 & 4.19 \\
\hline 3 & 2.81 & 3.07 & 6.51 & 6.59 & 3.97 & 4.24 \\
\hline F-test & NS & NS & NS & NS & NS & NS \\
\hline \multicolumn{7}{|c|}{ Inter action } \\
\hline $\mathrm{B} \times \mathrm{M}$ & NS & NS & NS & NS & NS & NS \\
\hline $\mathrm{B} \times \mathrm{N}$ & NS & NS & NS & NS & NS & NS \\
\hline $\mathrm{M} \times \mathrm{N}$ & NS & NS & NS & NS & NS & NS \\
\hline $\mathrm{B} \times \mathrm{V} \times \mathrm{N}$ & NS & NS & NS & NS & NS & NS \\
\hline
\end{tabular}

Table 5. Alkaline, purity $\%$ and sugar percentage as affected by boron levels, methanol levels and time of methanol foliar applications in 2012/2013 and 2013/2014 seasons.

\begin{tabular}{|c|c|c|c|c|c|c|}
\hline \multirow{2}{*}{ Factor } & \multicolumn{2}{|c|}{ Alkaline } & \multicolumn{2}{|c|}{$\begin{array}{l}\text { purity\% } \\
\text { seasons }\end{array}$} & \multicolumn{2}{|c|}{ sugar percentage } \\
\hline & $2012 / 2013$ & $2013 / 2014$ & $2012 / 2013$ & $2013 / 2014$ & $2012 / 2013$ & $2013 / 2014$ \\
\hline \multicolumn{7}{|c|}{ Boron fertilizer rate $(\mathrm{Kg} / \mathrm{fad}).(\mathrm{B})$} \\
\hline 0 & 2.31 & 2.13 & $89.71 \mathrm{a}$ & $89.76 \mathrm{a}$ & $17.04 \mathrm{c}$ & $17.52 \mathrm{c}$ \\
\hline 1 & 2.36 & 2.34 & $88.73 b$ & $88.57 \mathrm{~b}$ & $17.39 \mathrm{~b}$ & $17.93 b$ \\
\hline 1.5 & 2.43 & 2.28 & $87.94 \mathrm{c}$ & $87.06 \mathrm{c}$ & $18.63 \mathrm{a}$ & $18.36 \mathrm{a}$ \\
\hline $\mathrm{F}$-test & NS & NS & $* *$ & $* *$ & $* *$ & $* *$ \\
\hline \multicolumn{7}{|c|}{ Concentration of methanol \%. (M) } \\
\hline $15 \%$ & 2.40 & 2.23 & $88.96 \mathrm{a}$ & $88.85 \mathrm{a}$ & $17.29 b$ & $17.76 \mathrm{~b}$ \\
\hline $30 \%$ & 2.36 & 2.25 & $88.81 \mathrm{ab}$ & $88.47 \mathrm{ab}$ & $17.44 b$ & $17.86 \mathrm{~b}$ \\
\hline $45 \%$ & 2.35 & 2.27 & $88.61 b$ & $88.07 \mathrm{~b}$ & $18.32 \mathrm{a}$ & $18.18 \mathrm{a}$ \\
\hline $\mathrm{F}$-test & NS & NS & $* *$ & $* *$ & $* *$ & $* *$ \\
\hline \multicolumn{7}{|c|}{ No. of foliar methanol (N) } \\
\hline 0 & 2.39 & 2.23 & 88.59 & 88.57 & $17.08 \mathrm{~d}$ & $17.68 \mathrm{~d}$ \\
\hline 1 & 2.37 & 2.24 & 88.76 & 88.58 & $17.54 \mathrm{c}$ & $17.86 \mathrm{c}$ \\
\hline 2 & 2.36 & 2.24 & 88.87 & 88.55 & $17.83 \mathrm{~b}$ & $17.99 \mathrm{~b}$ \\
\hline 3 & 2.63 & 2.28 & 88.94 & 88.15 & $18.29 \mathrm{a}$ & $18.20 \mathrm{a}$ \\
\hline $\mathrm{F}$-test & NS & NS & NS & NS & $* *$ & $* *$ \\
\hline \multicolumn{7}{|c|}{ Inter action } \\
\hline $\mathrm{B} \times \mathrm{M}$ & NS & NS & NS & NS & NS & NS \\
\hline $\mathrm{B} \times \mathrm{N}$ & NS & NS & NS & NS & NS & NS \\
\hline $\mathrm{M} \times \mathrm{N}$ & NS & NS & NS & NS & NS & NS \\
\hline $\mathrm{B} \times \mathrm{V} \times \mathrm{N}$ & NS & NS & NS & NS & $* *$ & $*$ \\
\hline
\end{tabular}

Regarding to the effect of methanol application purity percentage of sugar beet juice, data in Table (5) distinctly cleared that increasing the applied doses of methanol from 15, 30 and $45 \%$ produced significant and gradual reducing in the values of purity. This finding was completely true in both 
seasons. These resulted are in harmony with these obtained by Abido (2012). Time of foliar application with methanol had no significant effect on purity $\%$ in both seasons. No significant interaction effect were found between three factors under study on purity $\%$ in both seasons

\section{5- Sugar percentage.}

Sucrose $\%$ in the important character in sugar beet because the final goal of sugar beet production depend on sucrose $\%$ and root yield. Data allocated in Table (5) pointed out that foliar application of boron on sugar beet at levels zero, 1 and $1.5 \mathrm{Kg} / \mathrm{fad}$. exhibited significant increase between mean values of sucrose $\%$ in both seasons. Maximum percentages were obtained in both seasons were 18.63 and $18.36 \%$ resp. resulted from addition $1.5 \mathrm{Kg} / \mathrm{fad}$. as foliar application compared to two other doses (zero and one $\mathrm{Kg} / \mathrm{fad}$.). This finding is in line with that found by Gobara and Mekki (2005), Ali Mekdad (2015), Mohammad et al, (2015) and Abbas et al (2014). They stated that sucrose $\%$ significantly increased with increasing boron doses.

Concerning the effect of methanol rates on sucrose \%, data in Table (5) revealed that the highest sucrose percentages 18.29 and $18.20 \%$ in both seasons were produced after addition methanol solution having concentration $45 \%$ compared with other two concentration (15 and 30\%) in both seasons. This advantage of methanol among be due to mode of action of methanol in increase carbohydrate accumulation and release photo respiration in plants. These observations are in agreement with those obtained by Abido (2012) and Nadali et al. (2010). As for the effect of methanol times of application on sugar beet data in Table (5) cleared that the highest of sucrose \% were found in both seasons 18.29 and $18.20 \%$ from addition methanol solution at three times more than other two times of applications.

Significant interaction effect between boron doses $\times$ methanol doses $\times$ times of methanol applications in both seasons resulted from addition boron fertilizer at rate of $1.5 \mathrm{Kg} / \mathrm{fad}$. and foliar application of methanol at rate of $45 \%$ three times in both growing seasons $(22.32 \%$ and $19.52 \%)$. This interaction cleared in Table (5-a).

\section{6- Sugar extractable\%, Extractability \% and Sugar losses \%.}

The three mentioned characters explain the quality of sugar beet juice and in find the gain for the producer of sugar beet. Extractable Sugar percentage was not significantly affected by addition boron levels in both seasons as foliar applications whereas, gradual increase was found and not reached to significant levels. Similar results were found by
Gobara and Mekki (2005) Once more. Data furnished in Table (6) illustrated that addition of methanol solution at dose $45 \%$ as foliar spraying to sugar beet gave the highest extractable sugar percentage in the second season only with significant differences between rates $45 \%$ and other two rates (15 and 30\%). On the other direction, in the first season no significant differences were found between means values of this due to effect of rates of methanol solution. These results are in harmony with those obtained by Nadali et al. (2010).

In respect to effect of times methanol spraying on extractable sugar \% the available data in Table (6) pointed out that no significant effect was found in the first season whereas, in the second season additio of Methanol at three times caused significant increase in extractable sugar \% (14.96\%) compared to the other treatments.

Extractability\% means the quantity of sugar which can extractable from total sucrose $\%$ to indicate the quality of root juice and the final sugar extractable.

Data in Table (6) revealed that. Extractability\% significantly decreased with increasing boron level from zero to $1.5 \mathrm{Kg} / \mathrm{fad}$. in both seasons.

Concerning the effect of methanol at level $45 \%$ superior than other two levels (15 and 30\%) and gave maximum values for this trait in both seasons.

Data in Table (6) showed that times of foliar addition failed exhibited any significant differences among values of this trait in both seasons.

Extractability\% not affected by the interaction between three factors under study in both seasons.

\section{7-Sugar losses:}

Sugar losses in molass are very important trait for sugar beet. So, any research should try to decrease this value in all cases. Data tabulated in Table (6) pointed out that significant increase in values of this trait with increasing the rates of boron fertilizer from zero to $1.5 \mathrm{Kg}$ / fad. as foliar spraying These results are true in both seasons. The finding are different with these obtained by Abbas et al. (2014) they found with increasing boron rates of boron from 0.0 to $0.25 \mathrm{~g} / \mathrm{L}$ caused to decrease sugar losses in molasses. Ali (2015) found that with increasing boron levels as foliar application significantly decreased sugar losses percentage in juice of sugar beet. Armin and Asgharipour (2012) found also that sugar loss decreased with increasing boron levels from 0.0 to $1.22 \mathrm{Kg} \mathrm{B} / \mathrm{ha}$. a water soluble $\mathrm{B}$ (Boric acid).

Data in Table (6) cleared that spraying methanol had bad effect on juice quality by increasing percentage and amount of sugar losses in molasses when used high rate on application (45\%) compared to other rates (15 and 30\%) which caused to decreased sugar losses in molasses. 
Table 5-a. Sugar percentage as affected by the interaction between boron fertilizer rate, concentration of methanol and times of application methanol in $2012 / 2013$ and 2013/2014.

\begin{tabular}{|c|c|c|c|c|c|c|c|c|c|}
\hline \multirow{4}{*}{$\begin{array}{l}\text { No. of foliar application of } \\
\text { methanol }\end{array}$} & \multicolumn{9}{|c|}{ Boron fertilizer rate $(\mathrm{Kg} / \mathrm{fad})}$. \\
\hline & \multirow{2}{*}{\multicolumn{3}{|c|}{0}} & \multirow{2}{*}{\multicolumn{3}{|c|}{$\begin{array}{c}1 \\
\text { Concentration of methanol }\end{array}$}} & \multirow{2}{*}{\multicolumn{3}{|c|}{1.5}} \\
\hline & & & & & & & & & \\
\hline & $15 \%$ & $30 \%$ & $45 \%$ & $15 \%$ & $30 \%$ & $45 \%$ & $15 \%$ & $30 \%$ & $45 \%$ \\
\hline \multicolumn{10}{|c|}{$2012 / 2013$ season } \\
\hline 0 & $16.76 \mathrm{rs}$ & $16.85 \mathrm{~s}$ & $16.75 \mathrm{rs}$ & $16.89 \mathrm{rs}$ & 16.93 qrs & $16.97 \mathrm{pqr}$ & $17.040-r$ & $17.42 \mathrm{kl}$ & $18.43 \mathrm{de}$ \\
\hline 1 & $16.87 \mathrm{rs}$ & $16.77 \mathrm{rs}$ & $17.05 \mathrm{o}-\mathrm{r}$ & $17.271-\mathrm{o}$ & $17.341-0$ & $17.45 \mathrm{jkl}$ & $17.57 \mathrm{~h}-1$ & $17.72 \mathrm{~g}-\mathrm{k}$ & $19.82 \mathrm{c}$ \\
\hline 2 & $17.06 \mathrm{~m}-\mathrm{r}$ & $17.05 n-r$ & $17.321-\mathrm{o}$ & $17.41 \mathrm{klm}$ & $17.55 \mathrm{~h}-1$ & 17.6h-1 & $17.79 f-d$ & $18.09 \mathrm{de}$ & $20.59 b$ \\
\hline 3 & $17.291-\mathrm{p}$ & $17.40 \mathrm{k}-\mathrm{n}$ & $17.58 \mathrm{~h}-1$ & $17.54 \mathrm{i}-1$ & $17.83 \mathrm{f}-\mathrm{i}$ & $17.90 \mathrm{fgh}$ & $18.06 f g$ & $18.65 d$ & $22.32 \mathrm{a}$ \\
\hline \multicolumn{10}{|c|}{$2031 / 2014$} \\
\hline 0 & $17.17 \mathrm{~s}$ & $17.27 \mathrm{rs}$ & $17.44 \mathrm{pqr}$ & 17.67 no & $17.79 \mathrm{k}-\mathrm{n}$ & $17.80 \mathrm{k}-\mathrm{n}$ & $17.91 \mathrm{i}-\mathrm{m}$ & $17.97 \mathrm{~h}-\mathrm{k}$ & $17.17 \mathrm{def}$ \\
\hline 1 & $17.30 \mathrm{rs}$ & $17.41 \mathrm{gr}$ & 17.62 nop & $17.76 \mathrm{lmn}$ & $17.86 \mathrm{j}-\mathrm{m}$ & $17.99 \mathrm{~g}-\mathrm{m}$ & $18.02 \mathrm{f}-\mathrm{d}$ & $18.16 \mathrm{efg}$ & $18.64 \mathrm{C}$ \\
\hline 2 & $17.41 \mathrm{qr}$ & $17.51 \mathrm{opq}$ & $17.73 \mathrm{mn}$ & $17.89 \mathrm{j}-\mathrm{m}$ & $17.95 \mathrm{ijk}$ & $18.15 \mathrm{e}-\mathrm{h}$ & $18.14 \mathrm{e}-\mathrm{h}$ & $18.27 \mathrm{de}$ & $18.87 \mathrm{~b}$ \\
\hline 3 & $17.64 \mathrm{no}$ & $17.75 \mathrm{mn}$ & $17.94 \mathrm{i}-1$ & $18.01 \mathrm{f}-\mathrm{j}$ & $18.08 \mathrm{f}-\mathrm{i}$ & $18.26 \mathrm{de}$ & $18.29 \mathrm{de}$ & $18.35 \mathrm{~d}$ & $19.52 \mathrm{a}$ \\
\hline
\end{tabular}


Table 6. Extractable sugar, extractability sugar and sugar losses to molasses \% as affected by boron and methanol levels and time of methanol foliar applications in 2012/2013 and 2013/2014 season.

\begin{tabular}{|c|c|c|c|c|c|c|c|c|}
\hline \multirow[t]{2}{*}{ Factor } & \multicolumn{2}{|c|}{ Extractable sugar $\%$} & \multicolumn{2}{|c|}{ extractability sugar\% } & \multicolumn{2}{|c|}{$\begin{array}{l}\text { sugar losses to molasses \% } \\
\text { seasons }\end{array}$} & \multicolumn{2}{|c|}{ TSS $\%$} \\
\hline & $2012 / 2013$ & $2013 / 2014$ & $2012 / 2013$ & $2013 / 2014$ & $2012 / 2013$ & $2013 / 2014$ & $2012 / 2013$ & $2013 / 2014$ \\
\hline \multicolumn{9}{|c|}{ Boron fertilizer rate (Kg/fad.) (B) } \\
\hline 0 & 13.95 & 14.35 & $81.85 \mathrm{a}$ & $81.92 \mathrm{a}$ & $2.49 \mathrm{c}$ & $2.57 \mathrm{c}$ & $19.99 \mathrm{c}$ & $20.83 c$ \\
\hline 1 & 14.04 & 14.49 & $80.79 b$ & $80.81 \mathrm{~b}$ & $2.75 b$ & $2.84 b$ & $20.27 b$ & $21.39 b$ \\
\hline 1.5 & 14.53 & 14.57 & $78.75 \mathrm{c}$ & $79.34 \mathrm{c}$ & $3.05 \mathrm{a}$ & $3.19 \mathrm{a}$ & $21.14 \mathrm{a}$ & $21.89 \mathrm{a}$ \\
\hline $\mathrm{F}$-test & NS & NS & $*$ & $* *$ & $* *$ & $* *$ & $* *$ & $* *$ \\
\hline \multicolumn{9}{|c|}{ Concentration of methanol \%. (M) } \\
\hline $15 \%$ & 14.02 & $14.38 b$ & $81.17 \mathrm{c}$ & $80.50 \mathrm{c}$ & $2.76 \mathrm{c}$ & $2.78 \mathrm{c}$ & $20.19 b$ & $21.15 \mathrm{c}$ \\
\hline $30 \%$ & 14.07 & $14.39 b$ & $80.68 b$ & $80.58 b$ & $2.77 b$ & $2.87 \mathrm{~b}$ & $20.30 b$ & $21.30 \mathrm{~b}$ \\
\hline $45 \%$ & 14.43 & $14.63 \mathrm{a}$ & $79.34 \mathrm{a}$ & $80.99 \mathrm{a}$ & $2.83 a$ & $2.95 \mathrm{a}$ & $20.92 \mathrm{a}$ & $21.66 \mathrm{a}$ \\
\hline $\mathrm{F}$-test & NS & $*$ & $*$ & $*$ & $* *$ & $* *$ & $* *$ & $* *$ \\
\hline \multicolumn{9}{|c|}{ No. of foliar methanol (N) } \\
\hline 0 & 13.76 & $14.26 \mathrm{~d}$ & 78.69 & 80.62 & 2.72 & $2.83 b$ & $19.79 d$ & 21.09 \\
\hline 1 & 14.19 & $14.41 \mathrm{c}$ & 80.53 & 80.70 & 2.75 & $2.85 b$ & $20.33 c$ & $21.27 \mathrm{c}$ \\
\hline 2 & 14.26 & $14.52 b$ & 81.10 & 80.72 & 2.77 & $2.87 \mathrm{ab}$ & $20.62 b$ & $21.43 b$ \\
\hline 3 & 14.46 & $14.96 \mathrm{a}$ & 81.26 & 80.73 & 2.80 & $2.91 \mathrm{a}$ & $20.97 \mathrm{a}$ & $21.70 \mathrm{a}$ \\
\hline $\mathrm{F}$-test & NS & $* *$ & NS & NS & NS & $*$ & $* *$ & $* *$ \\
\hline \multicolumn{9}{|c|}{ Inter action } \\
\hline $\mathrm{B} \times \mathrm{M}$ & NS & NS & NS & $\mathrm{NS}$ & NS & NS & NS & NS \\
\hline $\mathrm{B} \times \mathrm{N}$ & NS & NS & NS & NS & NS & NS & NS & NS \\
\hline $\mathrm{M} \times \mathrm{N}$ & NS & NS & NS & NS & NS & NS & NS & NS \\
\hline $\mathrm{B} \times \mathrm{V} \times \mathrm{N}$ & NS & NS & NS & NS & NS & NS & NS & NS \\
\hline
\end{tabular}


This was true in both seasons. Nadali et al. (2010) concluded that with increasing methanol rates from $7 \%$ to $35 \%$ caused slightly decrease in sugar in molasses without any significant differences between mean values of sugar in molasses.

Concerning to effect of time methanol application on sugar loss in molasses. Data in Table (6) revealed that significant differences between values of sugar loss in molasses in the second season only. Maximum lost on sugar in molasses was found with increasing times of application.

On the other direction times of application had no effect on this trait in the first season. No interaction effects were found in both seasons between three factors under study on sugar loss in molasses.

\section{8- Total soluble solids (TSS \%) percentage.}

Data collected in Table (6) clearly showed that total soluble solids\% were significant increase with increasing boron rates from zero to $1.5 \mathrm{Kg} / \mathrm{fad}$. This trait was increased from $19.99 \%$ to $21.14 \%$ in the first season and from 20.83 to $21.89 \%$ in second season with increasing boron levels from zero to 1.5 $\mathrm{Kg} \mathrm{B} / \mathrm{fad}$. Similar findings were found by Gobara and Mekki (2005).

Regarding to foliar methanol solution at different rates from 15 to $45 \%$ on sugar beet (TSS \%). Data in table (6) reveal this influence and exhibited significant differences among values of this trait in both seasons. Spraying methanol solution at rate of $45 \%$ gave the maximum values (20.92 and $21.66 \%$ ) in both seasons compared with the lowest values (20.19 and $21.15 \%)$ which obtained with spraying lowest rates $15 \%$.

Regarding the effect of times of methanol solution on total soluble solids (TSS \%). Data presented in table 6 obviously cleared that addition methanol solution at three times as foliar spraying on sugar beet significantly increased values of TSS\% in both seasons compared with other three treatments. These resulted may be due to effect of high concentration of methanol by increased times of application cause an increase in accumulation of sucrose and carbohydrate and other substances in cells.

No significant interaction effects were found between all factor under study in both seasons on total soluble solids (TSS \%).

\section{Reference}

Abbas, M.S., M.H. Dewdar, E.L. Gaber and H.A. Abd EL-Aleem (2014). Impact of boron foliar application on quantity and quality traits of sugar beet (Beta Vulgaris L.) in Egypt. Res. J. phama. Bio. Chem.. Sci,5(5): 143-151.

Abido W.A.E. (2012). Sugar beet productivity as affected by foliar spraying with methanol and boron. Int. J. Agric. Sci., 4 (7): 287-292.
Ali, A.A.M. (2015). Sugar beet productivity as affected by nitrogen fertilizer and foliar spaying with boron. Int. J. curr. Microbial App. Sci. 4 (4): 182-196.

Armin, M. and M. Asgharipour (2012). Effect of time and concentration of boron foliar application on yield and quality of sugar beet. Am. Euras. J. Agric. \& Environ. Sci., 12(4): 444-448.

Carruthers A.; J.V. Dutton; J.F.T. Oldfield; M. Shore and H.J. Teague (1960). Juice composition in relation to factory performance 13th. Ann. Technol conf. Biritish sugar corporation Ltd $36 \mathrm{pp}$.

Cooke, D.A. and Scott, R.K. (1993). The sugar crop. Chapman and Hall, London, pp. 262-265.

Devillers, P. (1988). Prevision du sucre melasse sucrerie feanases 190-200. (C.F. The Sugar Beet Crop. Book).

Dexter, S.T.; M.G. Frankes and F.W. Snyder (1976). A rapid and practical method of determining extractable white suagr as may be applied to the evaluation of agronomic practices and grower deliveries in the sugar beet industry. J. Am., soc., sugar beet Technol. 14:433-454.

Duncan, B.D. (1955). Multiple range and multiple F. test Biometric 11:1-42.

Gezgum, S., M. Hamurcu and M. Apaydin (2001). Effect of boron application on the yield and quality of sugar beet. Turkish J. Agric. And Forestry, 25: 89-95.

Gomes, K.A. and A.A. Gomes (1984). Statistical procedures for agricultural research. An. International Rice research institute Book John Willey and Sons. Inc., New York.

Gobara Mirvat and Mekki, B.B. (2005). Influence of boron application on yield and juice quality of some sugar beet cultivars grown under saline soil conditions. J. Appl. Sci. Res., 1 (5): 373-379.

Gout E., Aubert S., Bigny R., Rebeille F., Nonmura A. R., Benson A. A. and Douce R. (2000). Metabolism of methanol in plant cells carbon-13 nuclear magnetic resonance studies. Plant physiology 123, 287-296.

Iman Nadali, M. Yarnia, F. Paknejad, F. Farahvash and S. Vazan (2014). Effect of methanol in promoting sugar beet (Beta vulgaris L.) yield and some quality characteristic in Drougth stress condition. Ball. Env. Pharmacol, life Sci., Vol 3 (11) October 57-61.

Jaszczolt, E. (1998). Effect of two methods of fertilizing sugar beet with trace elements on the yield of roots and sugar. Gazeta. Cukrowniaza 106: 232-234.

Le-Doct, A. (1927). Commercial determination of sugar beet root using the saches - Le-Doct process int. Sug. J., 29:488-492. (C.F. suagr beet Nutrition, 1927. Appl. Sci. Pub. Ltp. London, P. Drycott).

Lee, H.S., M. Madhaiyan, C.W. Kim, S. J. Choi, K.Y. Chung, T.M. (2006). Physiological 
enhancement of early growth of Rice seedling (Oryza Sativa L.) by production of phytohormone of N2-fixing methylotrophic. Bio. Fertile. Soils. 42: 402-408.

Mohamed, D.H.D., M.S. Abbas, E.I. Gaber and A. EL-Aleem (2015). Influence of time addition and rates of boron foliar application on growth quality and yield traits of sugar beet. Int. curr. Microbial App. Sci. 4(2): 231-238.
Nadail, I.; Paknejad, F., Moradi, F., Vazan, S., Tookalo, M., Jami AL- Ahmed, M. Pazoki A.(2010). Effect of foliar application of methanol on sugar beet (Beta Vulgaris L). Australian J. of Crop Sci., 4 (6): 398-401.

Silin, P.M. and N.P. Silina (1977). Chemistry control in sugar technology food. Tech. pub. USSR, P. 167.

\title{
تأثر محصول وجودة بنجر السكر بتركيزات البورون ونسب و مواعيد اضافة الميثانول.
}

\author{
هيثم السيد أحمد نعمت الله ، السيد أحمد السيد نعت الله ' سعد سعد زلط \\ معهز بحوث المحاصيل السكرية - مركز البحوث الزراعية - الجيزة.
}

أقيمت تجربة حقليه كررت في الموسمين الزراعيين 2013/2012، 2014/2013 لدراسة تأثير الاضافه رشا لكلا من البورون

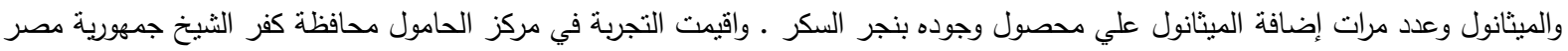
العربية. وقد استخدم التصميم الإحصائئ القطع المنشقه مرتين Strip-plot design حيث تم وضع معدلات التسميد بالبورون (صفر ، 1 ، 1.5

كجم/ف) في صورة حمض البوريك في القطع العمودية وضعت معدلات الميثانول (15 ، 30 ،45\%) و عدد مرات رش الميثانول بعد ( 55 ، أ 70 ، 85 ) من الزراعه في القطع الافقبيه.

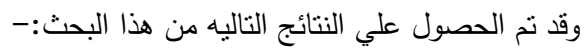

ـ - ادت زيادة معدل رش البورون من صفر الئ1.5 كجم/ف الي زيادة كلا من قطر الجذر وطوله ونسبة الجذر الى العرش وكنلك

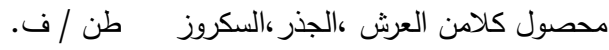

بالنسبة لصفات الجودةاظهرت النتائج ظهور عدم تأثر معامل القلويه بأضافة البورون في كلا الموسمين واظهرت النقاوة فروقا معنويه

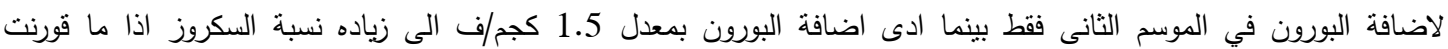

بالمعدلات الاخرى الاقل منها.

زادت قيم الثوائب (Na, K, 2 في كلا الموسمين زيادة معنويه بزيادة معدل اضافة البورون الي 1.5 كجم/ف .ولم يكن هناك

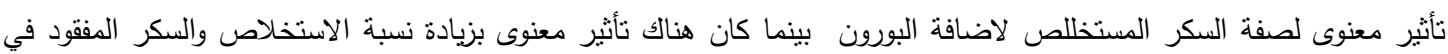

المولاس وكذلك المواد الصلبة الذائبة الكلية.

كان لاضافة محلول الميثانول بتركيز ( 45\% ) تأثير معنوى موجب بزيادة قيم الصفات التاليه طول الجذر - نسبة الجذر/العرش ومحصول العرش والجذروالسكروز بالطن/ ف وكذلك محتوى الجذور من الثوائب (Na, K, a-N) قى كلا الموسمين وكنلك النقاوه

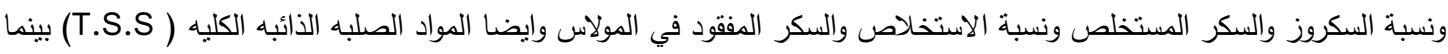
لم يكن لاضافة الميثانول اى تأثير معنوى بأى معدل من المعدلات المستخدمه على معامل القلويه فى الموسمين وكذا السكر

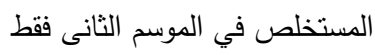
كما كان لعدد مرات رش الميثانول بمعدل 45\% ثلاث مرات اثر معنوى بزيادة قيم كلا من طول وقطر الجذر - نسبة الجذر / العرش

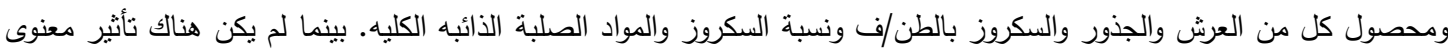

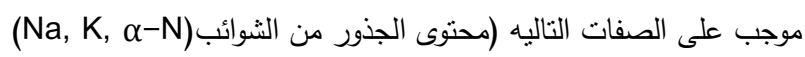
ومعامل القلويه -النقاوه - نسبة الاستخلاص.

واخيرا يمكن القول بان الدراسه قد توصلت الى ان ش البورون بمعدل 1.5 كجم/ف وكذلك الميثانول بتركيز 45\% ثلاث

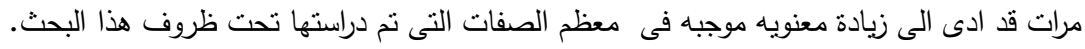

